\title{
PENGEMBANGAN BELAJAR BERBASIS ANEKA SUMBER (BEBAS)
}

\section{Eveline Siregar}

\begin{abstract}
The development of science and technology is improved rapidly brings about the sources of learning vary as well. This condition facilitates learners in studying independently. This article wants to discuss the definitions of the sources of learning, the technology types of the sources of learning, the benefits of the variety resource based learning, and the ways of learning and using the sources of learning.
\end{abstract}

Keywords: development of learning, types of the sources of learning, resources based learning.

\section{PENDAHULUAN}

Dalam upaya mewujudkan masyarakat belajar (learning community) harus diciptakan kondisi sedemikian rupa yang memungkinkan peserta didik memiliki pengalaman belajar melalui berbagai sumber. Sumber belajar yang dimaksud baik sumber yang dirancang (by design) maupun sumber yang dimanfaatkan (by utilization) untuk keperluan pembelajaran. Di sisi lain tuntutan pendidikan seperti kebutuhan akan kurikulum yang berbasis kompetensi, belajar terbuka, belajar jarak jauh, dan belajar secara luwes mendorong dimanfaatkannya berbagai sumber belajar secara luas.

Sejalan dengan perkembangan ilmu dan teknologi, sumber belajar semakin lama semakin bertambah banyak jenisnya. Sehingga memungkinkan orang dapat belajar mandiri secara lebih baik. Pergeseran dari era industri ke era informasi menuntut perubahan dalam berbagai bidang, termasuk pendidikan. Di era informasi, peserta didik setiap saat dihadapkan pada berbagai informasi dalam jumlah jauh lebih banyak dibandingkan pada masa-masa sebelumnya. Informasi tersebut disebarkan melalui berbagai media, baik cetak maupun elektronik, dari yang berteknologi sederhana sampai yang sudah canggih seperti penggunaan CD-ROM dan internet.

Jika peserta didik tidak dipersiapkan untuk dapat memberi makna terhadap informasi, menciptakannya menjadi pengetahuan, menggunakan serta mengevaluasi pengetahuan yang diciptakan orang lain, mereka akan selalu tertinggal. Begitu juga di tempat kerja, Rose \& Nicholl (1997) mengemukakan bahwa pengetahuan meningkat dua kali lipat setiap dua atau tiga tahun dalam hampir setiap lapangan pekerjaan. Ini berarti bahwa pengetahuan yang kita miliki juga harus meningkat dua kali lipat setiap dua atau tiga tahun kalau ingin bertahan.
Pada kesempatan ini penulis bermaksud menyampaikan salah satu isu mutakhir pendidikan, yaitu mengenal lebih dekat aneka sumber belajar dalam pengembangan belajar.

\section{PEMBAHASAN}

\section{Sumber belajar}

Sumber belajar menurut AECT, meliputi semua sumber yang dapat digunakan oleh pelajar baik secara terpisah maupun dalam bentuk gabungan, biasanya dalam situasi informasi, untuk memberikan fasilitas belajar. Sumber itu meliputi pesan, orang, bahan, peralatan, teknik, dan tata tempat. Sumber belajar dapat dibedakan menjadi 2 jenis: 1) sumber belajar yang direncanakan, yaitu semua sumber yang secara khusus telah dikembangkan sebagai komponen sistem instruksional untuk memberikan fasilitas belajar yang terarah dan bersifat formal; dan 2) sumber belajar karena dimanfaatkan, yaitu sumber-sumber yang tidak secara khusus didesain untuk keperluan pembelajaran, namun dapat ditemukan, diaplikasikan dan digunakan untuk keperluan belajar.

Menurut Dictionary of Instructional Technology (1986), any resources (people, instructional materials, instructional hardware, etc) which may be used by a learner to bring about or facilitate learning. Percival \& Ellington (1988) mengatakan bahwa sumber belajar yang dipakai dalam pendidikan atau latihan adalah suatu sistem yang terdiri dari sekumpulan bahan atau situasi yang diciptakan dengan sengaja dan dibuat agar memungkinkan siswa belajar secara individual. Sumber belajar inilah yang disebut media pendidikan atau media instruksional. Untuk menjamin sumber belajar yang cocok, sumber belajar harus memenuhi 3 persyaratan sebagai berikut.

1. Harus dapat tersedia dengan cepat.

2. Harus dapat memungkinkan siswa untuk memacu diri sendiri. 
3. Harus bersifat individual, misalnya harus dapat memenuhi berbagai kebutuhan para siswa dalam belajar mandiri.

Dorrel (1993), learning resources is the phrase that will be used to describe learning materials which includes videos, books, audio cassettes, CBT and TV programs, together with learning packages which combine any of these media. Menurut Seels \& Richey (1994), sumber belajar adalah manifestasi fisik dari teknologi - perangkat keras, perangkat lunak, dan bahan pembelajaran. Manifestasi fisik teknologi dapat dikategorikan dalam 4 jenis teknologi, yaitu teknologi cetak, teknologi audiovisual, teknologi berasaskan komputer, dan teknologi terpadu.

1. Teknologi cetak

Cara untuk memproduksi atau menyampaikan bahan seperti buku-buku dan bahan-bahan visual yang statis, terutama melalui proses pencetakan mekanis atau fotografis.

2. Teknologi audiovisual

Cara memproduksi dan menyampaikan bahan dengan menggunakan peralatan mekanis dan elektronis untuk menyampaikan pesan-pesan audio dan visual.

3. Teknologi berbasis komputer

Cara-cara memproduksi dan menyampaikan bahan dengan menggunakan perangkat yang bersumber pada mikroprosesor.

4. Teknologi terpadu

Cara untuk memproduksi dan menyampaikan bahan dengan memadukan beberapa jenis media yang dikendalikan komputer.

\section{Belajar Berbasis Aneka Sumber}

Dorrell mengatakan bahwa istilah belajar berbasis aneka sumber terkait dengan istilah lainnya, "resource-based learning is a broad heading used to cover all the above, i.e. open learning, distance learning, and flexible learning, in which the use learning resources is the main thrust of any scheme developed". Menurut Dorrell, penggunaan berbagai sumber belajarlah yang merupakan pendorong dikembangkannya sistem belajar terbuka, belajar jarak jauh, dan belajar fleksibel sehingga istilah belajar berbasis aneka sumber sebenarnya sudah tercakup di dalamnya.

Istilah belajar berbasis aneka sumber (resourcebased learning) adalah istilah yang sangat luas, encompassing a wide range of means by which students are able to learn in ways that are on a scale from those that are mediated by tutors to those where the students are learning independently. (Brown \& Smith, 1996). Menurut Brown \& Smith, sebenarnya istilah belajar berbasis aneka sumber bukanlah sesuatu yang baru karena siswa telah lama menggunakan sumber belajar seperti buku, kemudian terjadi peningkatan penggunaan media termasuk bahan-bahan belajar terbuka, petunjuk belajar, petunjuk buku teks, buku kerja, paket-paket video, dan audio. Akibat perkembangan teknologi, siswa dimungkinkan untuk menggunakan media canggih termasuk:

1. computer-based learning packages;

2. computer conference;

3. CD-ROM, multimedia;

4. computer-mediated discussion groups;

5. interactive video discs;

6. materials on the World Wide Web; dan

7. teleconferencing, video-conferencing dan telematics.

\section{Manfaat Belajar Berbasis Aneka Sumber}

Belajar berbasis aneka sumber memberikan berbagai keuntungan, keuntungan yang diperoleh antara lain sebagai berikut.

1. Selama pengumpulan informasi terjadi kegiatan berpikir yang kemudian akan menimbulkan pemahaman yang mendalam dalam belajar (McFarlane, 1992).

2. Mendorong terjadinya pemusatan perhatian terhadap topik sehingga membuat peserta didik menggali lebih banyak informasi dan menghasilkan hasil belajar yang lebih bermutu (Kulthan, 1993).

3. Meningkatkan keterampilan berpikir seperti keterampilan memecahkan masalah, memberikan pertimbangan-pertimbangan, dan melakukan evaluasi melalui penggunaan informasi dan penelitian secara mandiri (Resnick,1987; Todd \& Inc Nicholas, 1995).

4. Meningkatkan perolehan ketrampilan pemrosesan informasi secara efektif, dengan mengetahui sifat dasar informasi dan keberagamannya (Cleaver, 1986).

5. Memungkinkan pengumpulan informasi sebagai proses yang berkesinambungan sehingga mengakibatkan terbentuknya pengetahuan pada tiap fase berikutnya (Moore, 1995).

6. Meningkatkan sikap murid dan guru terhadap materi pembelajaran dan prestasi akademik (Cuel, 1991).

7. Membuat orang antusias belajar dan terinspirasi untuk berpartisipasi aktif (Wilbert, 1976).

8. Meningkatkan prestasi akademik dalam penguasaan materi, sikap dan berpikir kritis (Barrilant, 1965). 
Menurut Dorrell (1993), belajar berbasis aneka sumber memberikan beberapa keuntungan bagi peserta didik sebagai berikut.

1. Memungkinkan untuk menemukan bakat terpendam pada diri seseorang yang selama ini tidak tampak. Tidak saja pada masa sekolah, tapi perkembangan terus berlanjut sepanjang hidup, memungkinkan perluasan wawasan dan harapan.

2. Dengan menggunakan sumber belajar, memungkinkan pembelajaran berlangsung terus menerus dan belajar menjadi mudah diserap dan lebih siap diterapkan. Keterampilan dan pengetahuan meningkat secara bersamaan.

3. Seseorang dapat belajar: sesuai dengan kecepatannya, sesuai dengan waktunya sendiri dan waktu kerja tanpa rasa takut akan persaingan, atau adanya orang lain (Big Brother) yang mengawasi.

Adapun manfaat belajar berbasis aneka sumber bagi organisasi adalah sebagai berikut.

1. Kesempatan belajar tersedia bagi lebih banyak orang.

2. Sumber-sumber untuk pra pelatihan dapat disediakan untuk memberikan pemahaman dasar di antara partisipan, hal ini dapat menghemat waktu pelatih dan uang serta waktu peserta.

3. Beberapa pelatihan seringkali dilakukan sepanjang tahun sesuai permintaan.

4. Penghematan terhadap biaya perjalanan dan akomodasi.

5. Belajar yang dilakukan terintegrasi dalam pekerjaan, akan lebih baik dan lebih cepat daripada dilakukan secara khusus (time away on a course).

6. Tenaga kerja akan lebih terdidik dan lebih terampil.

7. Orang akan lebih luwes dalam keahlian dan sikap mereka dengan belajar secara terus menerus.

8. Biaya yang dikeluarkan untuk pelatihan dalam bentuk ini dapat diketahui lebih dahulu sehingga dapat menghindari terjadinya anggaran yang berlebihan.

9. Kualitas bahan yang digunakan dapat konsisten dan tidak bergantung pada pelatih yang kadang-kadang kurang baik persiapannya.

10. Individu dapat bebas belajar, sementara ia menyesuaikan dengan beban kerjanya dan tidak perlu absen dari pekerjaan sepanjang waktu.
11.Timbulnya tanggung jawab dari manajer dan stafnya untuk melatih dan mengembangkan diri mereka sendiri pada saat mereka mengontrol proses belajarnya.

Berkenaan dengan keuntungan belajar berbasis aneka sumber yang melekat dalam belajar bagaimana belajar (learning to learn) Dorrel mengutip pernyataan Alan Mumford (1988) mengenai keuntungan belajar berbasis aneka sumber dapat sebagai berikut.

1. Meningkatkan kemampuan belajar.

2. Meningkatkan motivasi belajar.

3. Menumbuhkan kesempatan belajar yang baru.

4. Mengurangi ketergantungan pada atasan dan guru.

5. Melipatgandakan - membantu bawahan.

6. Menumbuhkan rasa percaya diri dalam menghadapi tantangan baru.

\section{Belajar Dengan Sumber Belajar}

Beberapa cara yang dapat digunakan bila metode belajar terbuka, belajar jarak jauh, atau belajar fleksibel diterapkan dengan menggunakan sumber belajar. Beberapa cara belajar tersebut antara lain sebagai berikut.

1. Pre course study.

Berkaitan dengan kemampuan peserta didik untuk menggunakan sumber belajar sebelum mengikuti pelatihan, yang dapat didisain dengan memperhitungkan kemampuan dasar yang harus dimiliki. Hal ini menguntungkan bagi pelatih bila partisipan memiliki tingkat pemahaman yang sama dan juga mempersingkat waktu pelatihan.

2. Post-course revision and refresher

Sumber belajar dapat digunakan berulang kali oleh mereka yang ingin memperdalam bahan pembelajaran bagi dirinya sendiri. Pada tahap berikutnya, bila menemukan kebutuhan tertentu atau ingin menggunakan apa yang sudah dipelajari, orang akan kembali mencari sumber belajar dan informasi yang diperlukan sebanyak mungkin untuk tujuan mereka sendiri.

3. Replacement of training courses

Pada kasus tertentu ada paket bahan belajar yang dapat menggantikan kebutuhan pelatihan untuk materi tertentu. Hal ini tidak dapat diterapkan untuk materi seperti keterampilan presentasi dan wawancara di mana kegiatan praktek dibutuhkan. Pada kasus lain, CBT atau video dapat memberikan materi pembelajaran selama atau sesudah kehadiran tutor. sehingga dapat menyelesaikan keseluruhan pembelajaran. 
4. Supplement to course work

Gagasan yang muncul adalah bila pembelajaran dilakukan di rumah menggunakan paket pembelajaran terbuka, yang seringkali membutuhkan sumber-sumber belajar pelengkap lainnya.

5. Creation of new modular courses

Bersama dengan organisasi pelanggan, menyediakan bahan-bahan belajar yang sifatnya unik untuk kebutuhan organisasi dalam bentuk sumber belajar seperti bahan cetak, audio, dan video, dll. Sumber-sumber belajar baru dapat diciptakan dalam bentuk modul. Hal ini dilakukan karena seringkali bahan belajar siap pakai yang tersedia sudah cukup memadai dan hanya membutuhkan sedikit perubahan pada bidang tertentu.

6. Initiation of individual effort

Bila sumber-sumber belajar disediakan dalam suatu organisasi dan bila diciptakan budaya dan suasana yang benar, seseorang akan menggunakan kesempatan belajar tersebut tanpa dorongan dari orang lain.

\section{KESIMPULAN}

Belajar berbasis aneka sumber sangat diperlukan untuk memenuhi tuntutan zaman dan perkembangan pendidikan sendiri. Dari uraian di atas beberapa hal dapat disimpulkan sebagai berikut.

1. Memasuki era informasi dan era perdagangan bebas yang penuh tantangan dan persaingan, dituntut tersedianya sumber daya manusia yang lebih berkualitas, yang menguasai ilmu pengetahuan dan teknologi serta produktif menghasilkan produk-produk bermutu.

2. Untuk mencapai hal tersebut, harus diciptakan suatu kondisi yang memungkinkan peserta didik memiliki pengalaman belajar dari berbagai sumber, baik sumber yang dirancang maupun yang dimanfaatkan.
3. Dengan belajar berbasis aneka sumber, peserta didik harus dibimbing untuk dapat "belajar bagaimana belajar" (learn how to learn).

4. Tugas pendidik adalah merencanakan, menciptakan, dan menemukan kegiatan yang bersifat menantang, yang akan membuat peserta didik berpikir, memberikan alasan logis, dan menggunakan pemikiran secara baik.

5. Organisasi pada umumnya dan penyelenggara pendidikan pada khususnya harus menyediakan berbagai sumber belajar guna menjamin berlangsungnya belajar yang terus menerus (continous learning).

\section{DAFTAR PUSTAKA}

AECT, (1977). Definisi teknologi pendidikan, Jakarta: Penerbit CV Rajawali.

Brown, S. \& Brenda S. (1996). Resource-based learning, London : Kogan Page Limited.

Dorrell, J. (1993). Resource based learning. London : Mc.Graw-Hill Book Company.

Ellington, H. \& Duncan H. (1986). Dictionary of instructional technology. London: Kogan Page.

Percival, F. \& Henry E. (1988). Teknologi pendidikan. Jakarta: Penerbit Erlangga.

Rose, C. \& Malcolm N. (1997). Accelerated learning for the $21^{\text {st }}$ century. London: Judy Piathus.

Seels, B. \& Rita C.R. (1994). Teknologi pembelajaran, definisi dan kawasannya. Jakarta: Unit Percetakan UNJ.

\section{KETERANGAN PENULIS}

Dra. Eveline Siregar, M.Pd., dilahirkan pada November 1958. Saat ini aktif sebagai dosen, pengajar di P3GK Sawangan, mitra kerja atau facilitator pada Kementrian Pemberdayaan Perempuan. Pendidikan terakhir yang ditempuh adalah pasca sarjana Teknologi Pendidikan UNJ. Salah satu buku yang pernah ditulisnya adalah Mozaik Teknologi Pendidikan yang diterbitkan tahun 2004. 